\title{
STRESS CORROSION CRACKING OF TITANIUM ALLOYS
}

PROGRESS REPORT: JULY 1 - SEPTEMBER 30, 1964

S. P. Rideout, M. R. Louthan, Jr,, and C. L. Selby
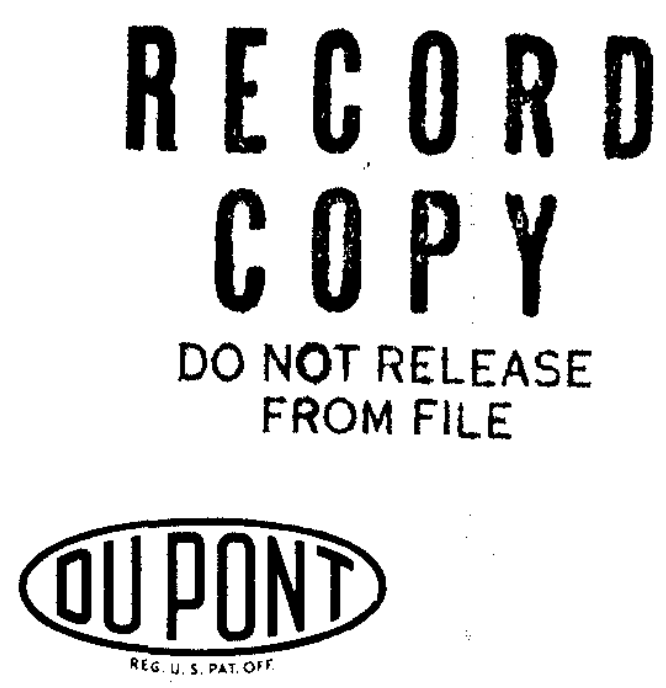

Savannah River Laboratory

Aiken, South Carolina 


\title{
STRESS CORROSION CRACKING OF TITANIUM ALLOYS \\ PROGRESS REPORT: JULY 1 - SEPTEMBER 30, 1964
}

\author{
by \\ Sheldon P. Rideout \\ McIntyre R. Louthan, Jr. \\ Clifford L. Selby \\ Approved by \\ P. H. Permar, Research Manager \\ Nuclear Materials Division

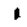 \\ December 1964

\begin{abstract}
Prepared for
National Aeronautics and Space Administration Work performed under NASA Purchase order No. R-124, Issued to the United States Atomic Energy Commission
\end{abstract}

\author{
E. I. DU PONT DE NEMOURS \& COMPANY \\ SAVANNAH RIVER LABORATORY \\ AIKEN, SOUTH CAROLINA \\ CONTRACT AT(07-2)-1 WITH THE \\ UNITED STATES ATOMIC ENERGY COMMISSION
}




\section{ABSTRACT}

Work was continued to determine the mechanism of stress corrosion cracking of titanium alloys exposed to hot chloride salts.

Metallographically polished strips of T1-8AlIMo-IV alloy that were stressed to the yield point at $650^{\circ} \mathrm{F}$ cracked within $3-1 / 2$ hours with a maximum depth of 0.022 inch after 14 days. A heavy oxide film appears to inhibit cracking.

Additional evidence was obtained indicating that $\mathrm{HCl}$ gas and presumably $\mathrm{NaOH}$ are formed during dehydration of sea salt; either or both may be involved in the corrosion.

Oxides formed at 900 and $1100^{\circ} \mathrm{F}$ on $8-1-1$ alloy are enriched with aluminum. Cracking may involve selective attack of this alloying element by $\mathrm{NaOH}$ or $\mathrm{NaCl}$.

of the four principal chlorides in sea salt, $\mathrm{NaCl}$ and $\mathrm{KCl}$ used indlvidually caused much more cracking than $\mathrm{MgCl}_{2}$ or $\mathrm{CaCl}_{2}$. The difference may be related to the relative strengths of the hydroxides of the cations. Radiotracers ${ }^{22} \mathrm{Na}$ and ${ }^{36} \mathrm{Cl}$ in sea salt are being used to study the roles of sodium and chlorine in the corrosion reactions. Traces of both were detected on cracked samples.

Transmission electron microscopy studies of the Ti-8AI-IMo-IV alloy were continued. 


\section{CONTENTS}

\section{$\underline{\text { Page }}$}

Introduction

4

Summary

4

Discussion 7

Procurement $\quad 7$

Experimental Procedure $\quad 7$

Experimental Results 8

References 22

\section{LIST OF TABLES AND FIGURES}

Table

I Heat Analyses of Ti-8Al-1Mo-IV Alloy 7

II Spark-Source Mass Spectrometer Analyses of Oxide Film on Ti-8Al-1Mo-IV Alloy 12

III Results of Tests Using Radiotracers ${ }^{38} \mathrm{Cl}$ and ${ }^{22} \mathrm{Na} \quad 16$

Figure

1 Microcracks at $\mathrm{NaCl}$ Contact Spots on Prepolished

Ti-8Al-1Mo-IV Alloy after 3-1/2 Hours at $650^{\circ} \mathrm{F}$

2 Crack Depth in Mill-Annealed Ti-8Al-1Mo-1V Alloy Strip, Stressed to Yleld at $650^{\circ} \mathrm{F}$ with Sea Salt Deposits

3 Microstructure at Salt Contact Spots on Prepolished T1-8A1-1Mo-IV Alloy Exposed I Day at Yield Stress at $650^{\circ} \mathrm{F}$ with Sea Salt Deposit

4 Accumulation of Chloride Ion in Water Trap in Effluent Air Stream BIown over Salt-Coated Chips of T1-8Al-IMo-1V Alloy at $650^{\circ} \mathrm{F}$

5 Effect of Cation in Chloride on Hot-Salt Stress Corrosion Cracking of Ti-8AI-1Mo-1V Alloy

6 Typical Load-Elongation Curve for Ti-8Al-1Mo-lV Alloy in the Duplex-Annealed Condition

7 Comparison of Beta Phase Particles in Metallographic Section and Tensile Rupture Surface

8 Electron Transmission Micrographs of T1-8Al-1Mo-1V Alloy in the Duplex-Annealed Condition

9 Dislocations in the Ti-8Al-1Mo-1V Alloy in the DuplexAnnealed Condition

10 Comparison of Hot-Salt Cracks Formed at 650 and $1200^{\circ} \mathrm{F}$ 


\section{STRESS CORROSION CRACKING OF TITANIUM ALLOYS \\ PROGRESS REPORT: JULY 1 - SEPTEMBER 30, 1964}

\section{INTRODUCTION}

Th1s is the second quarterly progress report of NASA-sponsored research by the Savannah R1ver Laboratory on the mechanlsm of hot-salt stress corrosion cracking of titanium alloys.

The objective of this research is to develop fundamental knowledge about the corrosion phenomena 1nvolved in cracking. Emphasis is being placed on study of the T1-8Al-1Mo-IV alloy because it is a prime candidate as a structural material for the proposed supersonic transport aircraft (SST). This alloy is known to be susceptible to hot-salt cracking in laboratory tests under conditions that may occur during operation of the SST, 1.e., skin temperature in the range of $550-650^{\circ} \mathrm{F}$ with salt contamination acquired during transoceanic operations.

Radioactive tracer elements are being used in studies of the chemical reactions that occur during inftiation and propagation of cracks. Electron microscopy techniques are being used to study crack morphology and to determine the effects of heat treatment and alloy structure on cracking.

Some incomplete or unconfirmed data may be included in these progress reports.

\section{SUMMARY}

\section{REVIEW OF FIRST QUARTER}

Tests performed during the first quarter ( 2$)$ indicated that heating sea salt alone to $650^{\circ} \mathrm{F}$ produced a volatile chloride-bearing product belleved to be HCl gas formed by dehydration. It was suggested that either the $\mathrm{HCl}$ gas or resultant hydroxides remaining in the salt may be involved in the inltiation of stress corrosion cracking.

"Salt sandwiches" made by clamping individual salt crystals between strips of Ti-8Al-IMo-IV alloy were heated 8 hours at temperatures from 400 to $1200^{\circ} \mathrm{F}$ in an attempt to observe the salt-metal reaction and obtain corrosion products for ldentification analyses. Visible corrosion products formed at temperatures $>800^{\circ} \mathrm{F}$. 
Electron microscopy studies revealed that:

- Cracks propagate along alpha phase grain boundaries and alphabeta phase interfaces.

- Cracks formed at $1200^{\circ} \mathrm{F}$ appeared to propagate by chemical attack with no evidence of mechanical rupture.

- The beta phase is cathodic to the alpha matrix.

Thin folls of the TI-8Al-IMo-1V alloy were successfully prepared for electron transmission studies of fine structure.

\section{SUMMARY OF SECOND QUARTER}

Stress corrosion cracking initiated very rapidly in metallographically polished strips of TI-8A1-IMo-1V alloy stressed to the yield point and heated at $650^{\circ} \mathrm{F}$. Cracks were visible after $3-1 / 2$ hours; the maximum crack depth in a duplex-annealed specimen after 14 days was 0.022 inch. An apparent difference in crack propagation rate was observed in two heats of the same alloy, one of which was mill-annealed and one-duplex annealed. Cracks propagated faster in the duplexannealed alloy.

Microscoplc examination of salt contact spots on polished surfaces indicated that the oxide $f 11 \mathrm{~m}$ was thinner in the area surrounding the spots (Figure 3). The oxide f1Im on the titanium alloy appears to protect against initiation of stress corrosion. A flame-oxidized sample had only three small cracks after 14 days at $650^{\circ} \mathrm{F}$, whereas samples with a polished surface had numerous cracks after the same exposure.

The composition of the titanium oxide film is being studied to determine if selective attack of alloying elements is involved in stress corrosion cracking. Preliminary analyses by spark-source mass spectrometer of films formed at 900 and $1100^{\circ} \mathrm{F}$ suggest that the ratio of aluminum to titanium is greater in the oxide than in the base metal (Table II).

Confirming evidence was obtained that HCl gas is given off during sea salt dehydration, and that most of the HCl gas is released during the first few hours of heating at $650^{\circ} \mathrm{F}$ (Figure 4). The possibility that HCl gas or resultant hydroxide in the salt is involved in the initiation of stress corrosion is being investigated. 
Tests comparing the degree of cracking caused by each of the four princlpal salts in sea salt ( $\mathrm{NaCl}, \mathrm{KCl}, \mathrm{MgCl}_{2}$, and $\mathrm{CaCl}_{2}$ ) showed that $\mathrm{NaCl}$ and $\mathrm{KCl}$ produced severe cracklng durling two weeks exposure at $650^{\circ} \mathrm{F}$, while $\mathrm{MgCl}_{2}$ and $\mathrm{CaCl}_{2}$ produced only a few tiny cracks (Figure 5). This may be related to the fact that sodium and potassium form strong hydroxides while magnesium and calcium form weak hydroxides.

Attempts to 1dentify the corrosion products of sea salt and $T 1$ metal have been unsuccessful. In order to reduce the complexity of corrosion products, pure $\mathrm{NaCl}$, which has been demonstrated to be an effective cracking agent, will be used instead of sea salt for future tests.

Separate tests using salt contalning radiotracer ${ }^{38} \mathrm{Cl}$ and salt contalning radiotracer ${ }^{22} \mathrm{Na}$ showed that small amounts of both ${ }^{36} \mathrm{CI}$ and ${ }^{22} \mathrm{Na}$ were present in cracked areas (Table III). An autoradiographic technique is being investigated, but has not yet been perfected, to determine the exact location of these radiotracers w1th respect to the cracks.

In duplex-annealed sheet material, the initiation of stress corrosion cracks appears to be independent of the orlentation of the sample with respect to the rolling direction. Room-temperature tensile tests of this material also showed no significant differences of mechanical properties or strain anisotropy in the longltudinal and transverse directions.

Transmission electron microscopy of thin foils of duplex-annealed T1-8Al-1Mo-IV alloy showed that the matrix was alpha phase and that the large second-phase particles were beta, phase. Structural features such. as dislocations, dislocation networks, and stacking faults were observed in many areas in the foll, suggesting that the stacking fault energy of the alloy was rather low. 


\section{DISCUSSION}

\section{PROCUREMENT}

A 4- by 8-foot sheet of 0.050 -inch-thick T1-8Al-1Mo-1V alloy was recelved from Langley Research Center. Sheet from the same heat, number D-5657, was used by Langley for studies of mechanical properties. This material was used in most of the tests during the second quarter and wiIl be used in all future tests.

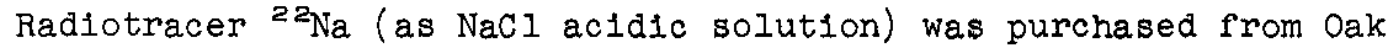
Ridge for studies of the role of sodium in the stress corrosion phenomenon. This 1sotope emits both beta and gamma radiation as follows:

$$
\begin{aligned}
{ }^{22 \mathrm{Na} \text { half-11fe }} & =2.58 \text { years } \\
\beta^{+} & =0.54 \mathrm{Mev} \\
\gamma & =1.28 \mathrm{Mev}
\end{aligned}
$$

This radiotracer was incorporated into a neutral saturated solution of $\mathrm{NaCl}$.

\section{EXPERIMENTAL PROCEDURE}

The initiation and propagation of hot-salt cracking was studied using metallographically pollshed strips of T1-8A1-1Mo-1V alloy. Two different heats of the alloy were used: TMCA D-3420 (0.030-inch sheet, mill-annealed), and TMCA D-5657 (0.050-inch sheet, duplex-annealed). Heat analyses are given in Table $I$. In order to obtaln results in a reasonable time, tests were performed at $650^{\circ} \mathrm{F}$ with samples stressed to the yield point.

\begin{tabular}{|c|c|c|}
\hline Element & $\begin{array}{c}\text { Composit } \\
\text { Heat No. D-3420 } \\
(0.030 \text {-inch sheet, } \\
\text { mill-annealed) } \\
\end{array}$ & $\begin{array}{l}\text { on, wt } \% \\
\text { Heat No. D-5657 } \\
(0.050-1 \text { nch sheet, } \\
\text { duplex-annealed) }\end{array}$ \\
\hline $\mathrm{c}$ & 0.023 & 0.026 \\
\hline $\mathrm{Fe}$ & 0.08 & 0.11 \\
\hline $\mathrm{N}$ & 0.012 & 0.011 \\
\hline Al & 7.7 & 7.9 \\
\hline $\mathrm{v}$ & 1.0 & 1.0 \\
\hline Mo & 1.0 & 1.1 \\
\hline $\mathrm{H}$ & $0.006-0.007$ & $0.003-0.006$ \\
\hline
\end{tabular}

\section{TABLE I}

Heat Analyses of T1-8A1-1Mo-1V Alloy 
Strips 3/4 inch by 3 inches were ground and polished on one surface, then stressed in a four-point loading sample holder to a calculated stress of 90,000 to 100,000 psi at room temperature. Salt was applied as droplets of a saturated neutral solution. Various forms of salt were used: natural sea salt, sea salt containing ${ }^{36} \mathrm{Cl}$, $\mathrm{NaCl}$ containing elther ${ }^{22} \mathrm{Na}$ or ${ }^{38} \mathrm{Cl}$, and individual chlorides of $\mathrm{K}, \mathrm{Mg}$, and $\mathrm{Ca}$. The samples were placed in a small muffle furnace at $250^{\circ} \mathrm{F}$ to dry the salt, then transferred to a muffle furnace at $650^{\circ} \mathrm{F}$ and exposed for various times up to 49 days. The stress level at $650^{\circ} \mathrm{F}$ was apparently at the yield point because the strips were slightly bowed when removed from the sample holders.

The strips were examined microscopically after the salt deposits were removed by swabbing in running water. Representative samples were sectioned to determine depth of cracking, while the remaining samples were studied by radiation counting techniques and/or autoradiography to determine the roles of chloride and sodium. In some cases the corroded surfaces were reground and repolished to determine if radiotracers remained in the cracked areas.

A few U-bend samples stressed to plastic yield were also exposed at $650^{\circ} \mathrm{F}$ for metallographic examinations.

\section{EXPERIMENTAL RESULTS}

\section{Initiation and Propagation of Cracking}

Stress corrosion cracking inftlated very rapldly in metallographically polished surfaces. Tiny cracks were observed microscopically at points of contact with NaCl crystals on one sample from heat D-5657 after only $3-1 / 2$ hours as 1llustrated in Figure 1 . Incipient cracking of samples from heat $\mathrm{D}-3420$ was also detected under deposits of sea salt after 5 hours.

Crack depths were measured on metallographic sections of samples from heat $\mathrm{D}-3420$ (m1li-annealed) exposed for perlods of 1 to 49 days and are plotted in Figure 2. Maximum crack depth was 0.005 inch after 1 day and 0.010 Inch after 49 days. No measurements were made on cracks that formed in less than 1 day, but the fact that cracks were visible on the surface after 5 hours indicates that the incubation period for cracking is less than 5 hours. The rate of crack propagation in these four-point loaded strip samples was much slower than in U-bend type samples of the same heat (D-3420) also exposed at $650^{\circ} \mathrm{F}$. After 14 days, the depth of cracking in U-bend samples was 0.020 to 0.025 inch. This difference in crack propagation rate is probably due to the combination of cold work of the metal during bending into the U-shape and the more complex stress patterns developed in the U-bend samples. 


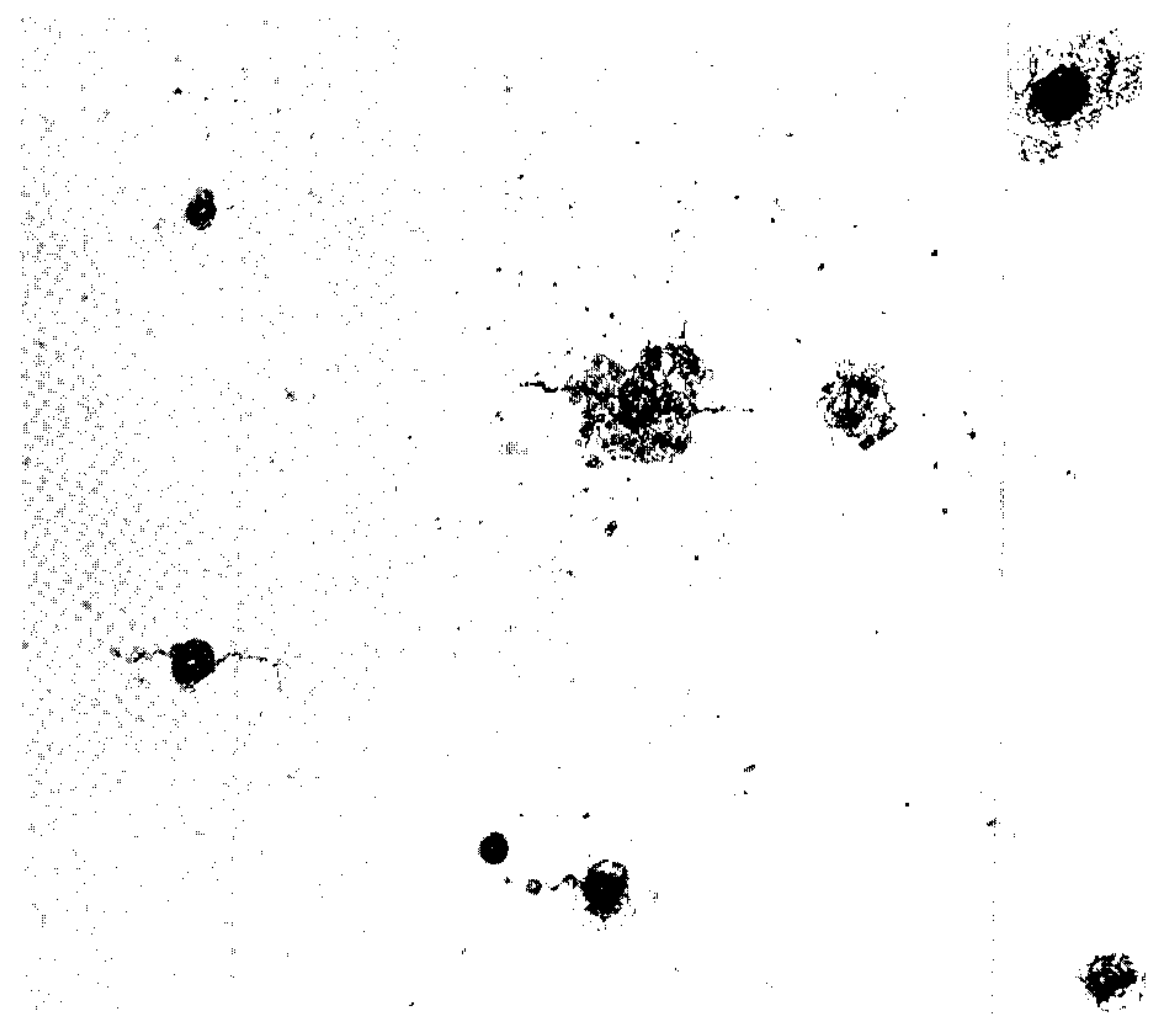

FIG. 1 MICROCRACKS AT NaCI CONTACT SPOTS ON PREPOLISHED Ti-8Al-1Mo-IV ALLOY AFTER $31 / 2$ HOURS AT $650^{\circ} \mathrm{F}$. Sample was duplex-annealed material, stressed to the yield stress at $650^{\circ} \mathrm{F} .250 \mathrm{X}$

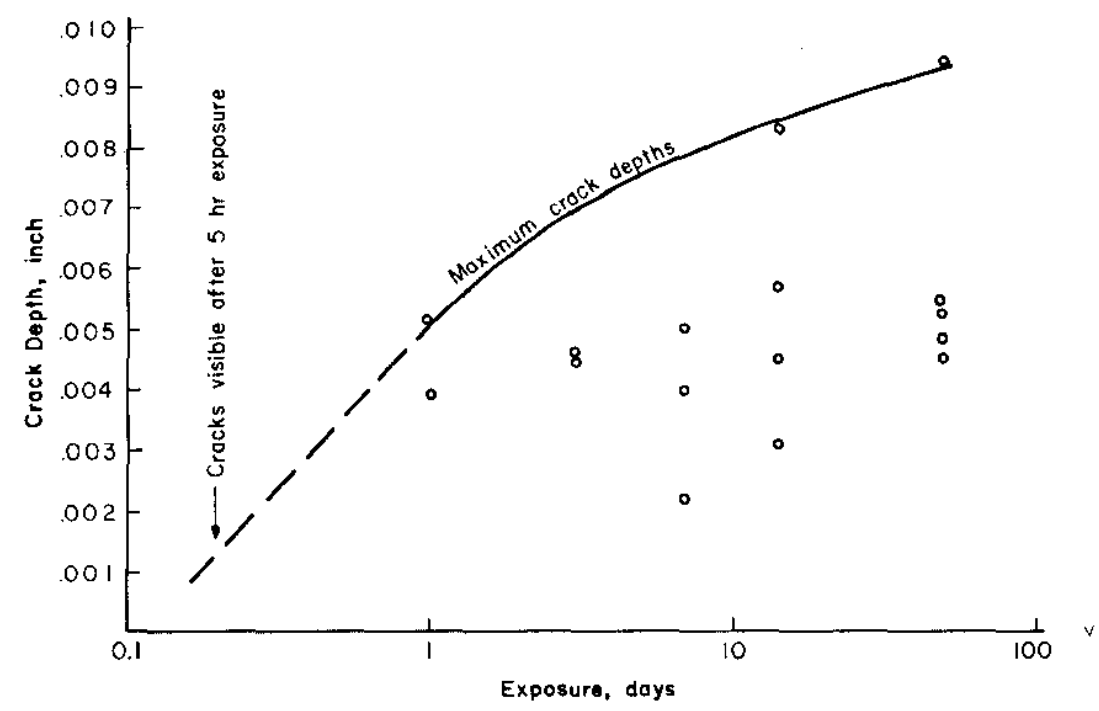

FIG. 2 CRACK DEPTH IN MILL-ANNEALED Ti-8AI-IMO-IV ALLOY STRIP, STRESSED TO YIELD AT $650^{\circ} \mathrm{F}$ WITH SEA SALT DEPOSITS 
The factors that influence the crack propagation rate have not been investigated in deta1l, but the propagation rate in the duplexannealed heat D-5657 was greater than in the mill-annealed heat D-3420. In four-point-loaded strip samples from D-5657 the maximum crack depth was 0.022 inch after 14 days at $650^{\circ} \mathrm{F}$.

The effects of alloy composition, cold work, heat treatments, stress level, and test temperature on the time to initiate cracking and the rate of propagation will be investigated in future tests.

\section{Examination of Salt Contact Spots}

Microscopic examination of sample surfaces after the excess salt had been removed revealed several interesting features. Flgure 3 shows the surface of a sample exposed 1 day at $650^{\circ} \mathrm{F}$ to a deposit of sea salt that was applied Initially as droplets of a saturated solution. Spots where individual salt crystals reacted with the metal were clearly visible. Pitting and cracking occurred at many of these spots. An unusual pattern of corrosion shown in area " $B$ " appeared to be related to some crystallographic feature of the salt crystal. The pattern was much larger than the size of the indlvidual grains in the metal, as is

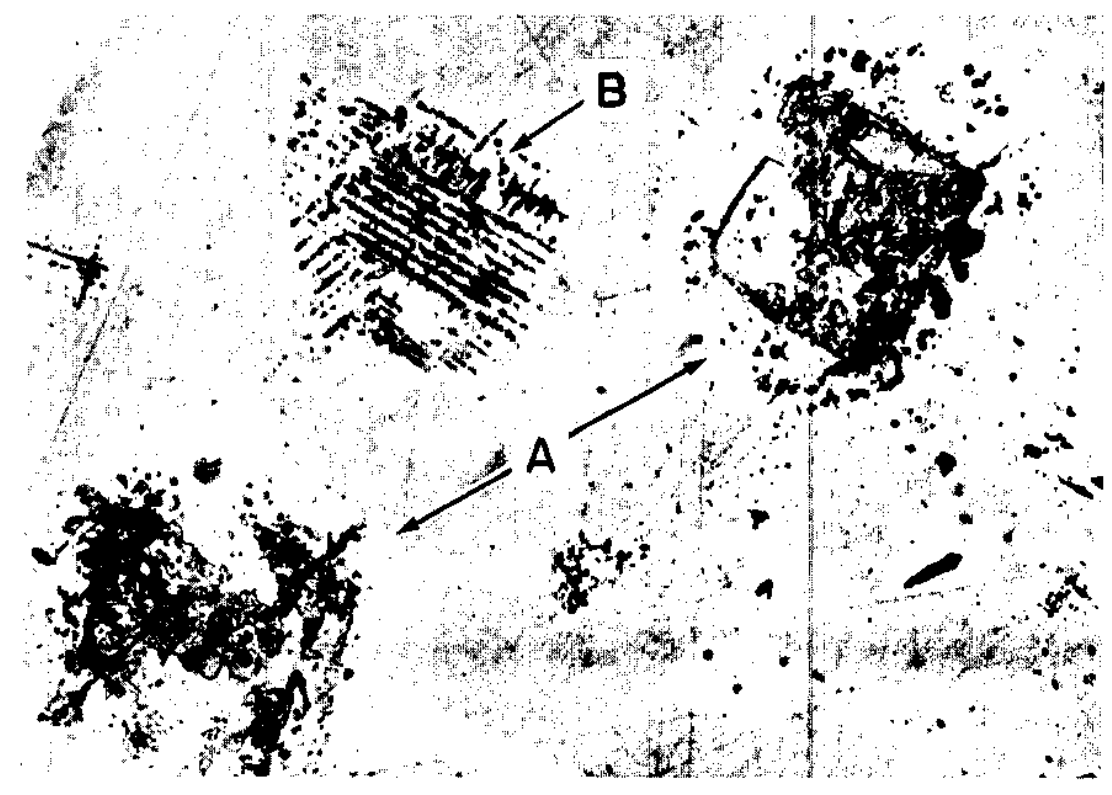

FIG. 3 MICROSTRUCTURE AT SALT CONTACT SPOTS ON PREPOLISHED Ti-8AL-1MO-IV ALLOY EXPOSED I DAY AT YIELD STRESS AT $650^{\circ} \mathrm{F}$ WITH SEA SALT DEPOSIT. Material was duplex-annealed. Note the tiny cracks and pits at $A_{;}$a corrosion pattern at $B$ related to erystallographic planes in salt crystal; and that the oxide film is apparently thinner around salt contact spots. $250 \mathrm{X}$ 
seen by comparison with Figure 10a. This observation may provide some insight to the mechanism of cracking, and will be investigated in more detail in the next quarter. A high resolution autoradiography technique will be used in future tests with salt contalning radiotracers ${ }^{22} \mathrm{Na},{ }^{36} \mathrm{Cl}$, and ${ }^{3} \mathrm{H}$ (tritium) to study these initial stages of saltmetal corrosion.

Another interesting feature shown in Figure 3 is that the oxide film on the polished metal surface is lighter (more reflective) at salt contact spots, which implies either that the oxide did not grow as rapidly in these areas, perhaps because of the presence of a reducIng atmosphere (HCl gas), or that the oxide was consumed during the salt-metal reaction.

\section{Role of Surface Oxide}

The rapid initiation of cracking in polished surfaces and the results of microscopic examination of salt contact spots described above suggested that the initiation of hot-salt cracking may be strongly influenced by the nature of the surface oxide film. Titanium is an extremely reactive metal which is prevented from corroding rapidiy in the atmosphere by the formation of a thin protective oxide film. If hot-salt cracking involves chemical reactions with the base metal, elther the reactants must diffuse through the oxide, or the oxide film must be dissolved by some reactant or mechanically ruptured. The first two mechanisms seem most likely.

Localized dissolution of the oxide or diffusion through it should depend on 1ts thickness and composition. The thickness and possibly the composition should depend on the temperature at which the oxide is formed. During this quarter studies were begun to determine the effect of heating at various temperatures on the composition of the oxide film and to determine the effect of these oxide films on initiation of stress corrosion cracking.

Preliminary analyses using a spark-source, double-focusing mass spectrometer siow that in oxide films formed at 900 and $1100^{\circ} \mathrm{F}$, the ratio of aluminum to titanium is quite variable, probably because the instrument examines a very small volume (a sphere of sample 20 microns in diameter). However the average aluminum-to-titanium ratio in the oxide is greater than in the base metal (Table II). This raises the possibility that the initiation and propagation of cracks involves selective attack of alloying elements. 


\section{TABLE II}

Spark-Source Mass Spectrometer Analyses of Oxide Film on T1-8Al-1Mo-1V Alloy.

\begin{tabular}{|c|c|c|c|c|c|c|c|c|c|}
\hline \multirow{3}{*}{$\begin{array}{c}\text { Temp of } \\
\text { Oxide } \\
\text { Formation, } \\
{ }^{\circ} \mathrm{F} \\
\end{array}$} & \multirow{3}{*}{$\begin{array}{c}\text { Tlme at } \\
\text { Temp, } \\
\text { hr } \\
\end{array}$} & \multirow[b]{3}{*}{ Spec1men } & \multicolumn{2}{|c|}{ Rat10 ${ }^{(a)}$ of } & Alloy & \multicolumn{4}{|c|}{ Element to $\mathrm{T} 1$, wt $\% \times 100$} \\
\hline & & & \multicolumn{3}{|c|}{ Oxide } & \multicolumn{4}{|c|}{ Base Metal (b) } \\
\hline & & & $\mathrm{Al} / \mathrm{T} 1$ & $\mathrm{~V} / \mathrm{T1}$ & $\underline{M 0} / T_{1}$ & $\mathrm{~A} 1 / \mathrm{T} 1$ & $\mathrm{~V} / \mathrm{Ti}_{1}$ & $\underline{M O} / \mathrm{T} 1$ & \\
\hline \multirow[t]{5}{*}{900} & 3 & 1 & 19.5 & 0.98 & 0.26 & & & & \\
\hline & & 2 & 71.4 & 0.72 & 0.23 & & & & \\
\hline & & 3 & 6.7 & 1.24 & 0.66 & . & & & \\
\hline & & 4 & 102.0 & 74 & 0.34 & & & & \\
\hline & & Avg & 50.0 & 0.92 & 0.37 & & & & \\
\hline \multirow[t]{3}{*}{1100} & 3 & 1 & 56.9 & 0.78 & 0.45 & & & & \\
\hline & & 2 & 21.4 & 0.74 & 0.30 & & & & \\
\hline & & Avg & 39.2 & 0.76 & 0.38 & 23.1 & $1.2=$ & 0.51 & \\
\hline
\end{tabular}

(a) These ratios are calculated assuming that the sensitivity of detection is unity. The sensitivity is not unity, but sensitivity is constant for a given matrix. Therefore, the ratios shown for the base metal can be used as a qualitative reference to determine if a given element is enriched in the oxide.

(b) Average of ratios from 12 individual determinations.

Only one test has been performed to date to determine the effect of oxide film thickness on stress corrosion cracking. A strip of TI8Al-1Mo-IV alloy was heated in an oxy-acetylene flame to produce a thin adherent scale. The strip was then cut longitudinally, and onehalf was ground and polished. Both pleces were then stressed in the same holder, sea salt was applied, and the holder was placed in a muffle furnace at $650^{\circ} \mathrm{F}$ for 14 days. After removal of the excess salt, numerous cracks were visible on the polished sample, but the scaled sample had only three tiny cracks near the edge along which the cut was made. These cracks were not visible until the surface scale was removed by light grinding and polishing. The difference in susceptibility to cracking was not due to heating effects on the structure because the polished half received the same heat treatment. This test indicates that a heavy oxide fllm may protect against initiation of cracking which agrees with previous reports that anodized surfaces resist cracking(B). These studies are continuing.

Tests using the 1sotope ${ }^{18 \mathrm{O}_{2}}$ to determine the role of oxygen in the corrosion phenomenon have not been started. Preliminary considerations have indicated that mass spectrometric analyses do not appear to be feasible for tracking the behavior of this nonradioactive isotope. A sultable alternative technique has not yet been developed. 


\section{Role of Moisture and $\mathrm{HCl}$ Gas}

Previous tests(1) using natural sea salt and sea salt containing radiotracer ${ }^{3}{ }^{8} \mathrm{Cl}$ provided evidence that a volatile chlorine-bearing product, tentatively identified as $\mathrm{HCI}$ gas, is given of when elther salt alone or salt-coated chips of titanlum alloy are heated at $650^{\circ} \mathrm{F}$. The HCl gas presumably is generated during dehydration. During this quarter, confirming evidence was obtained that the product $1 \mathrm{~s} \mathrm{HCl}$ gas and not volatile metal chlorides.

Thin chips of T1-8Al-IMo-IV alloy were placed in a glass boat and $5 \mathrm{ml}$ of saturated sea salt solution was added. The mixture was evaporated to dryness on a warm hot plate at about $200^{\circ} \mathrm{F}$. The $s a m p l e$ was then placed in a tube furmace at $650^{\circ} \mathrm{F}$, and dry air was blown over the sample, through a glass wool fllter, and then bubbled through deionized water. The water was removed after various times and replaced each time with fresh water. The water samples were analyzed for $\mathrm{Cl}^{-}$, $\mathrm{Na}, \mathrm{K}, \mathrm{Mg}, \mathrm{Ca}, \mathrm{Ti}$, and $\mathrm{Al}$. Slgniflcant concentrations of $\mathrm{Cl}^{-}$were found, but only traces of the metallic elements were present (parts per billion range), indicating that the product must be HCl gas. The concentration of chloride ion was far in excess of that which would be formed by dissociation of chlorine gas in the water. However, this does not preclude the possibility that a trace of chlorine gas was present. The fact that $\mathrm{CI}^{-}$was detected when salt alone was heated provides additional evidence that the product is HCl gas.

Most of the HCl gas was given of during the first few hours of heating. This is shown in Figure 4, in which chloride ion concentration expressed as ppm accumulated in the water per hour of air flow is plotted against test time. The apparent sudden release of chloridebearing product during the second hour of heating will be investigated further to determine the influence of moisture in the salt and in the oxide film and whether this effect is reproducible. It is expected that moisture in the salt plays the major role in determining the quantity of HCl given off. The moisture content is apt to vary among samples, and therefore the quantitative amount of $\mathrm{Cl}^{-}$accumulated in the water may vary somewhat in multiple tests of the type described above.

Studies are continuing to determine if $\mathrm{HCl}$ gas or the resultant $\mathrm{NaOH}$ is involved in stress corrosion. E1ther of these chemicals could selectively attack aluminum in the oxide and base metal. Evidence of $\mathrm{NaOH}$ in salt-metal corrosion products was reported by Martin, (2) who suggested that $\mathrm{NaOH}$ was a product of the corrosion reactions. The SRL evidence suggests that $\mathrm{NaOH}$ may be a reactant. 


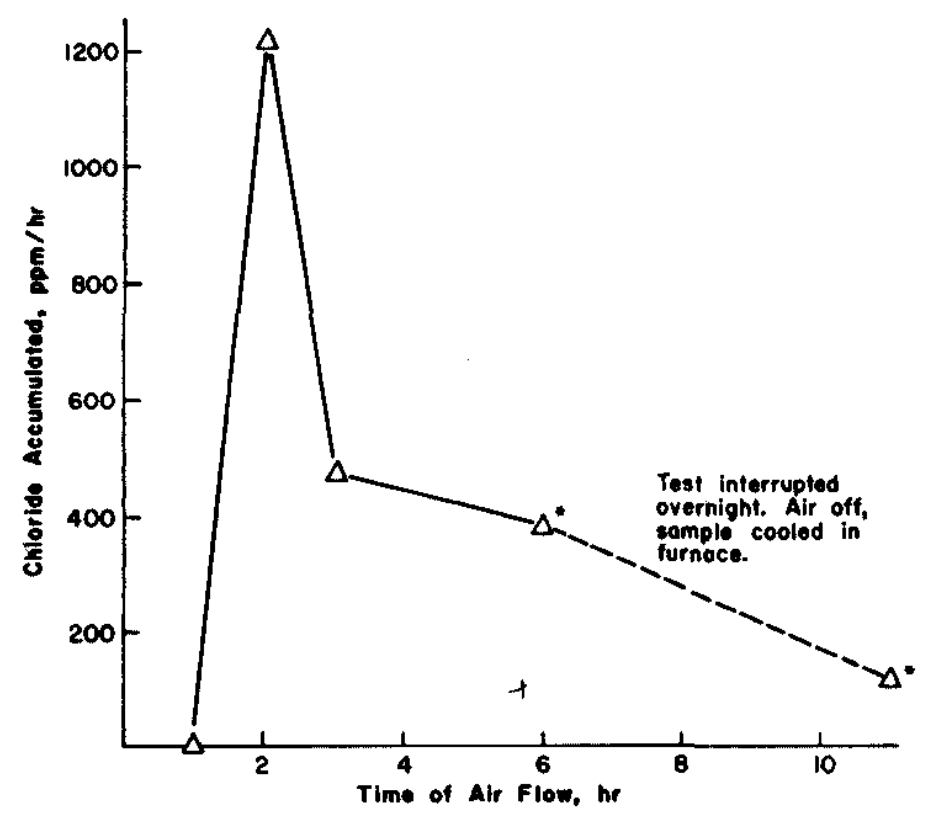

FIG. 4 ACCUMULATION OF CHLORIDE ION IN WATER TRAP IN EFFLUENT AIR STREAM BLOWN OVER SALT-COATED CHIPS OF Ti.8AI-1Mo-1V ALLOY AT $650^{\circ} \mathrm{F}$. *Averages for single water samples used continuously for 3 hours.

Role of Cotions in Salt

Sea salt contains four princlpal chlorides: $\mathrm{NaCl}, \mathrm{KCl}, \mathrm{MgCl}_{2}$, and $\mathrm{CaCl}_{2}$. Tests performed during the quarter to determine if cracking behavior is influenced by the cation species revealed that $\mathrm{NaCl}$ and $\mathrm{KCl}$ are much more aggressive than $\mathrm{MgCl}_{2}$ and $\mathrm{CaCl}_{2}$.

Droplets of saturated solutions of each of these four individual chlorides were dried on polished-and-stressed samples that were subsequently exposed 14 days at $650^{\circ} \mathrm{F}$. After exposure, the excess salt was washed off and the sample surfaces were IIghtly repolished (no grinding) for microscoplc examination. As shown in Figure 5, $\mathrm{NaCl}$ and KCl caused severe pltting and cracking, while only a few tiny cracks, which were very difficult to find, occurred on samples exposed to $\mathrm{MgCl}_{2}$ and $\mathrm{CaCl}_{2}$.

These results may be related to the strengths of hydroxides of these cations. $\mathrm{NaOH}$ and $\mathrm{KOH}$ are both strong bases, whereas $\mathrm{Mg}(\mathrm{OH})_{2}$ and $\mathrm{Ca}(\mathrm{OH})_{2}$ are both weak bases.

In order to minimize the complexity of reactions and products involved in hot-salt cracking studies, future tests will use only $\mathrm{NaCl}$. 


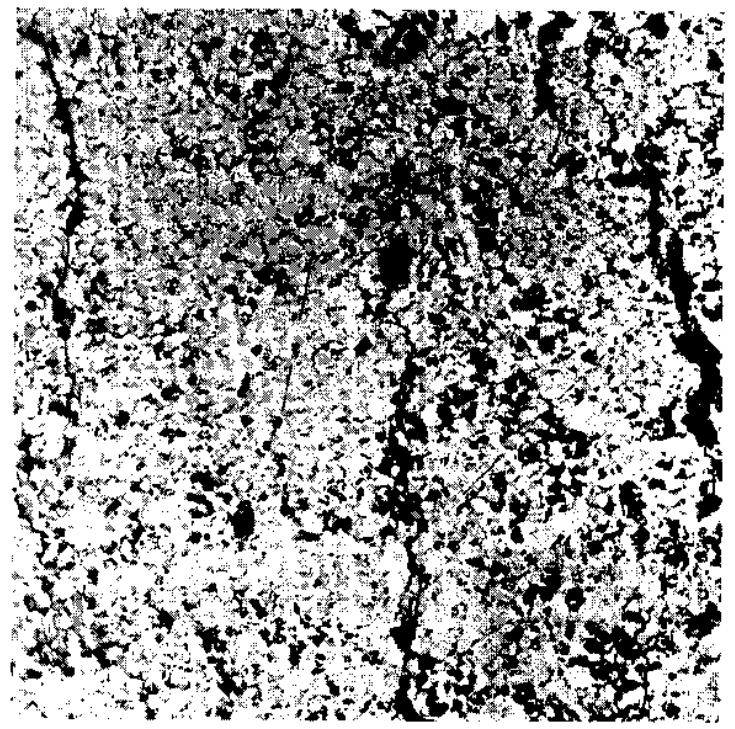

a. $\mathrm{NaCl}$

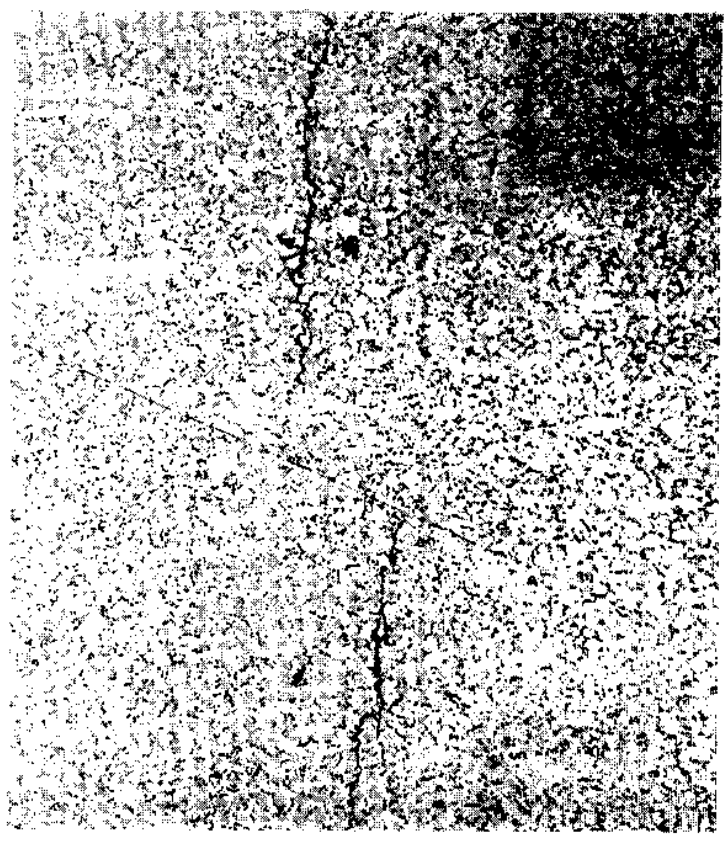

c. $\mathrm{MgCl}_{2}$

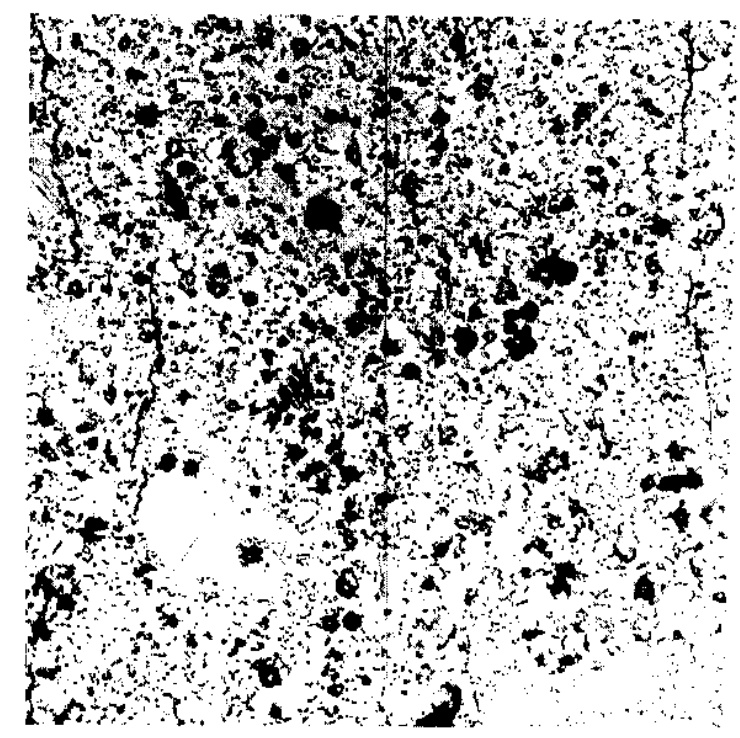

b. $\mathrm{KCl}$

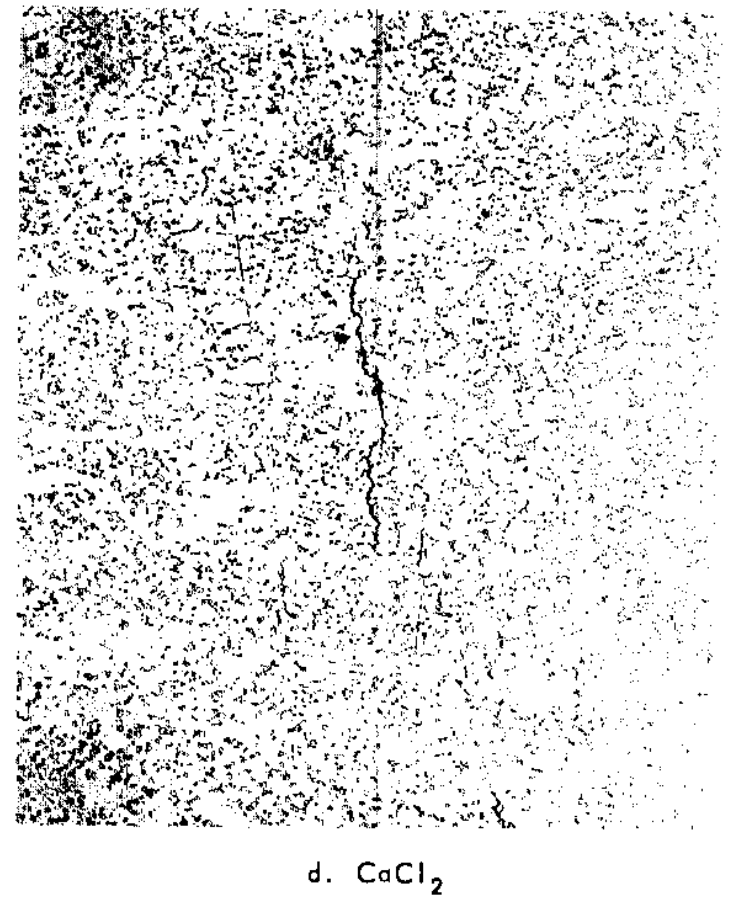

FIG. 5 EFFECT OF CATION IN CHLORIDE ON HOT -SALT STRESS CORROSION CRACKING OF Ti-8AI-1Mo-IV ALLOY. Samples wereduplex-annealed material (Heat D.5657), prepolished, coated with individual salts indicated above, and exposed 14 days at $650^{\circ} \mathrm{F}$ at the yield stress. Excess salt removed by washing and repolishing. $250 \mathrm{x}$ 


\section{Identification of Corrosion Products}

Attempts to use X-ray diffraction for identification of corrosion products produced in "salt sandwiches" exposed at various temperatures during the first quarter have been unsuccessful. The "salt sandwich" technique of observing the salt-metal reaction has been abandoned in favor of microscopic examination of salt contact spots on prepolished surfaces.

A hot-stage X-ray diffraction technique is being considered for studies to identify corrosion products generated "In situ."

Tests with Radiotracers ${ }^{36} \mathrm{Cl}$ and ${ }^{22} \mathrm{No}$

Radiotracers ${ }^{36} \mathrm{Cl}$ and ${ }^{22} \mathrm{Na}$ are being used in studies of hot-salt corrosion. Traces of both ${ }^{38} \mathrm{Cl}$ and ${ }^{22} \mathrm{Na}$ have been detected by radiation counters in cracked samples after all excess salt and corrosion products were removed by washing, light grinding, and polishing. However, a high-resolution autoradiography technique has not yet been perfected for determining the exact location of these elements with respect to the cracks.

Typical radioactivity counter results are summarized in Table III. The level of radioactivity was quite low after removal of excess salt. The low activity level may be due to removal of soluble chloride and sodium bearing reactants and products during washing. However, the fact that even traces of activity are present after light grinding and polishing indicates that both chloride and sodium are present either in the cracks or in micropits.

\section{TABLE III}

Results of Tests Using Radiotracers ${ }^{38} \mathrm{Cl}$ and ${ }^{22} \mathrm{Na}$

$$
\begin{gathered}
\begin{array}{c}
\text { Exposure, } \\
\text { days }
\end{array} \\
\text { at } 650^{\circ} \mathrm{F}(\mathrm{a}) \\
\hline
\end{gathered}
$$
7

14

$$
14
$$$$
14
$$$$
7
$$

Beta Radiation Detected, counts per minute

Sample Washed, Tracer Sample Washed Reground, and Polished 5 $30-60$ 70 $20-50$ 12 20-30

(a) Cracks occurred on all samples. 
In future tests the excess salt w1ll be removed by dry brushing and scraping so that soluble species can be retained in the corroded areas. Also, the role of hydrogen will be investigated by using ${ }^{3} \mathrm{H}$ (tritium) in the salt water used to apply the salt deposits.

\section{Effects of Sample Orientation in Rolled Sheet}

A limited number of tests were performed to compare the cracking behavior and mechanical properties of strip samples cut parallel to and transverse to the rolling direction of the duplex-annealed T18Al-1Mo-1V alloy sheet (heat D-5657). Sample orientation appeared to have no effect on initiation of cracking in strips with NaCl deposits exposed for various times from 5 hours to 14 days while stressed to the yield stress at $650^{\circ} \mathrm{F}$. Tiny cracks were visible after 5 hours in both types. Crack propagation rate was not determined.

Room-temperature tensile tests showed that the mechanlcal properties and strain anisotropy were approximately the same in the long1tudinal and transverse directions. The load-elongation curves for both directions were nearly identical and showed a definite inflection at approximately 9\% elongation (Figure 6). Metallographic examination of specimens tested to different points along the load-elongation curve revealed that the inflection corresponded to the initiation of twinning and the start of necking.

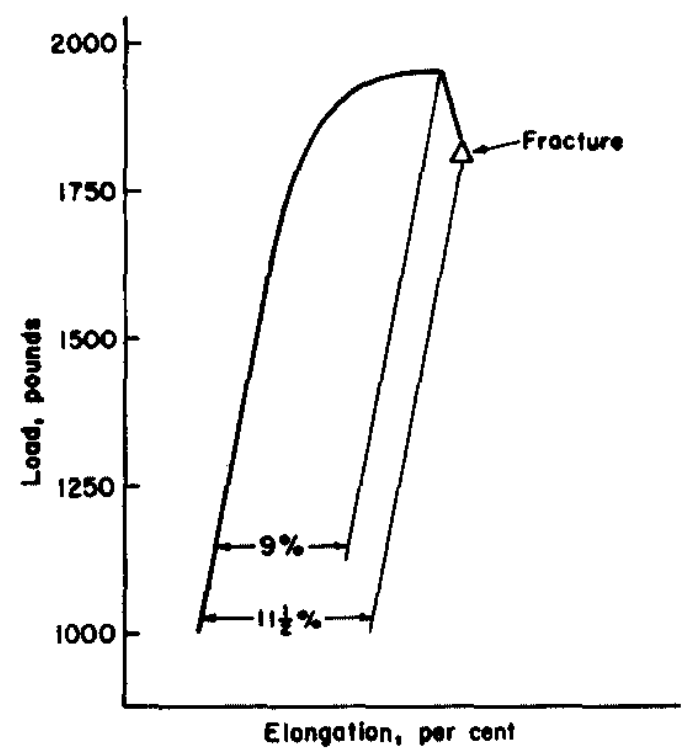

FIG. 6 TYPICAL LOAD-ELONGATION CURVE FOR Ti-8AI-IMO-IV ALLOY IN THE DUPLEX.ANNEALED CONDITION 
Fractography of the rupture surfaces on tensile samples showed that failure occurred predominantly by shear. As shown in Figure $7 \mathrm{a}$ and $\mathrm{b}$, comparison of the number of beta phase particles in a metallographic section with the number in the rupture surface indicated that fracture occurred through the alpha matrix with no preferential cracking along beta-alpha phase boundaries or through beta phase particles. This is in contrast to the preference for hot-salt stress corrosion cracking to occur along beta-alpha phase boundaries shown in Figure 10b.

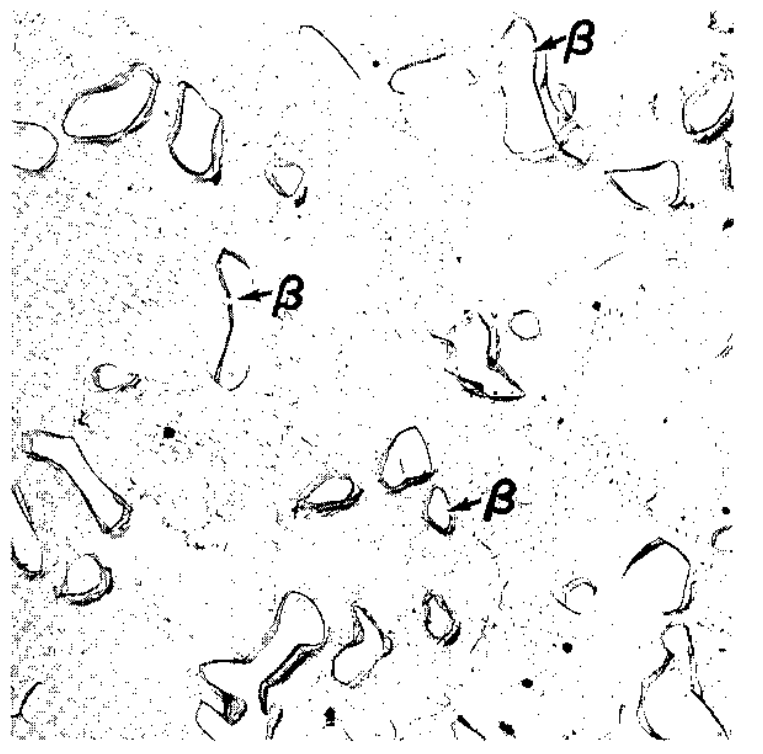

a. Metallographic section. Note the large number of beta particles.

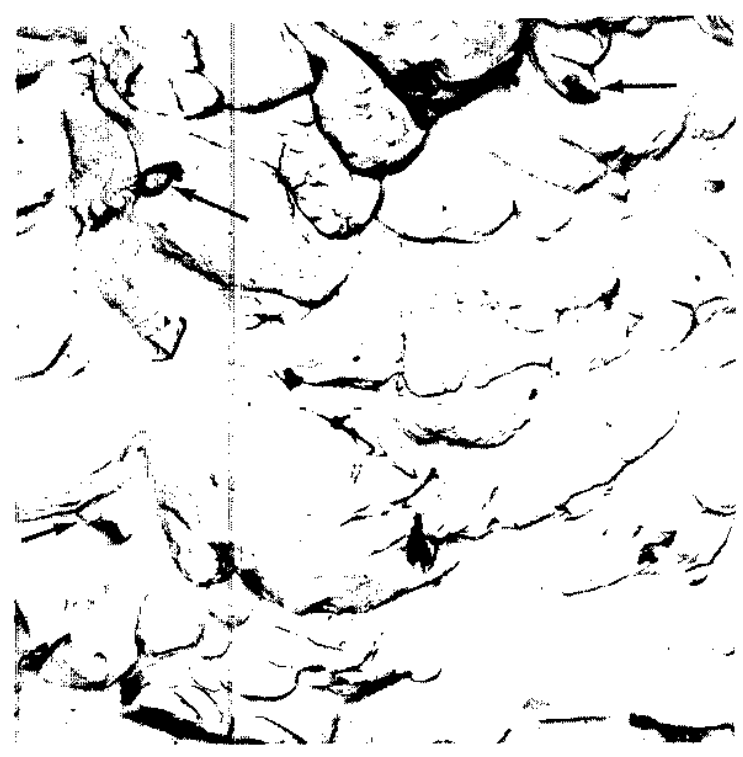

b. Tensile rupture surface. Note that little or no beta phase can be seen. Arrow points to possible beta particle.

FIG. 7 COMPARISON OF BETA PHASE PARTICLES IN METALLOGRAPHIC SECTION AND TENSILE RUPTURE SURFACE. The lack of evidence of beta phase in the tensile rupture indicates that the alloy had no preference for fracture along beta-alpha phase boundaries or through beta particles. $3200 \mathrm{X}$

\section{Electron Microscopy Studies}

During this quarter, transmission electron microscopy studies were directed toward further characterization of Ti-8Al-1Mo-1V alloy structure. Thin foils for transmission studies were prepared from the 0.050-inch-thick sheet of duplex-annealed alloy (heat D-5657). The structural appearance of many regions of this material (Figure 8 ) was similar to that seen previously in folls prepared from the 0.030 -inchthick sheet of mill-annealed alloy (heat D-3420). Selected-area electron diffraction studies revealed that the matrix was the hexagonal alpha phase and that the large second phase particles in the matrix 

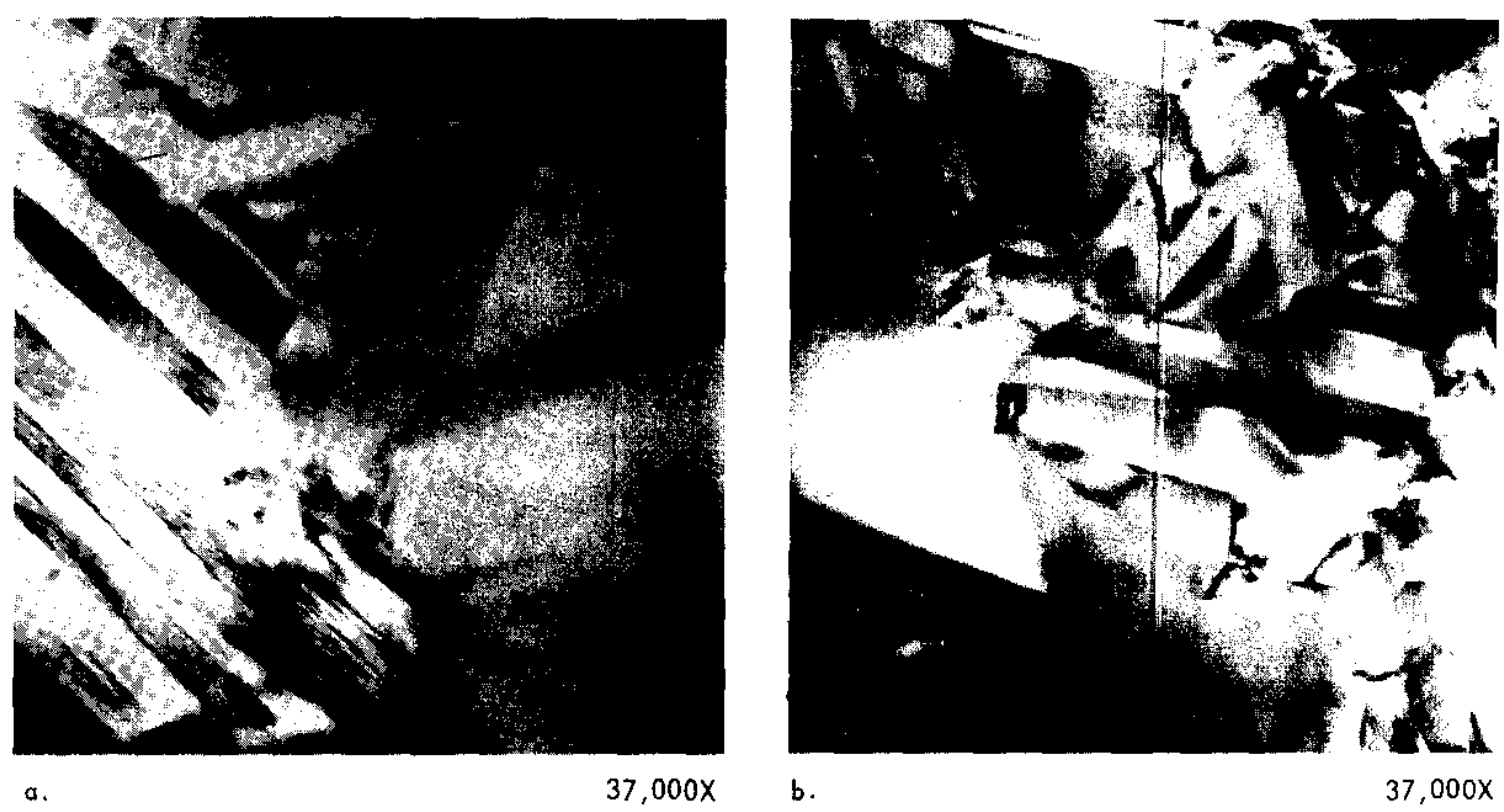

FIG. 8 ELECTRON TRANSMISSION MICROGRAPHS OF Ti-8AI-IMO-IV ALLOY IN THE DUPLEX-ANNEALED CONDITION
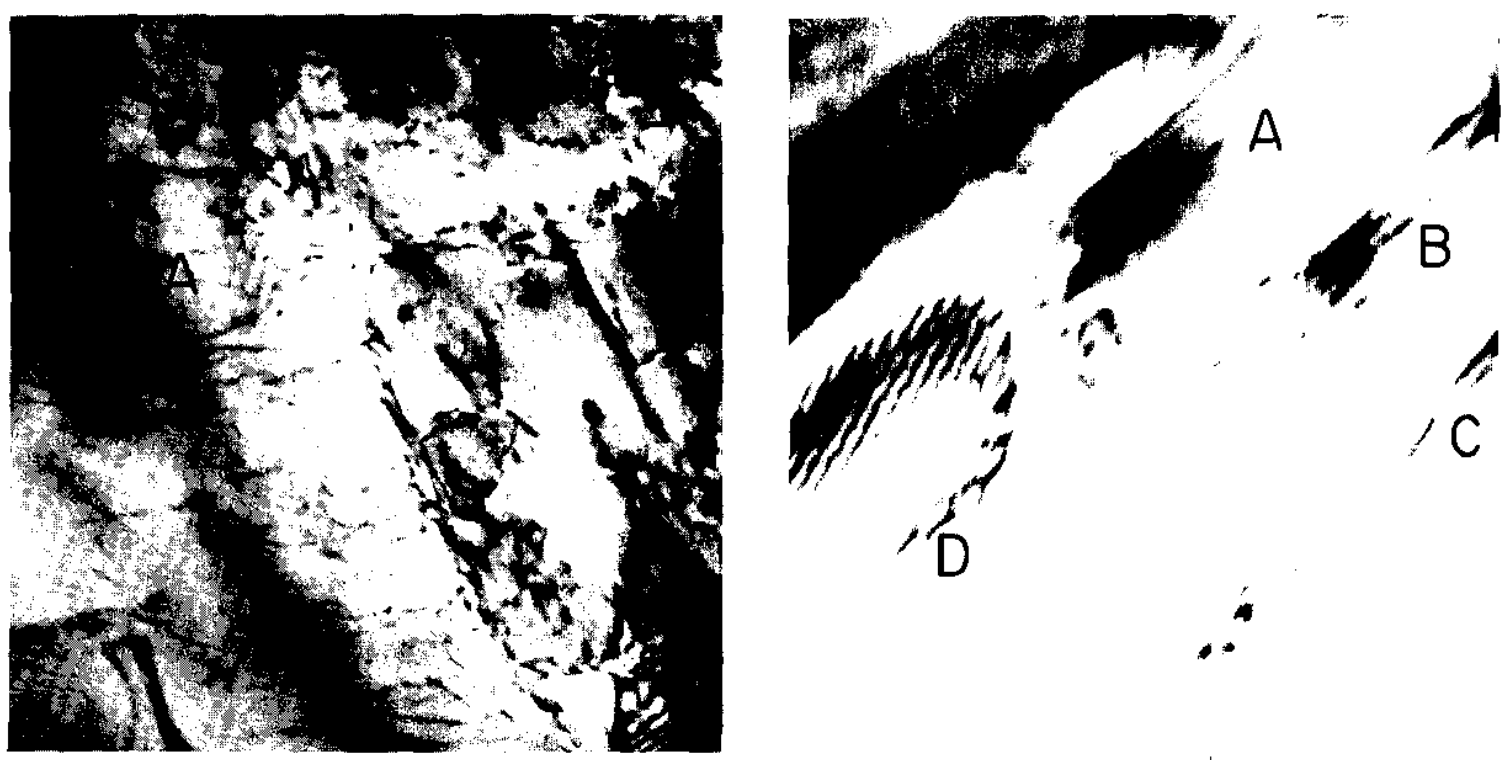

a.

Note coplanar arroy of dislocations at area $A$

Note stacking faults $A, B$, and $C$ and the hexagonal dislocation network with extended nodes of D

FIG. 9 DISLOCATIONS IN THE Ti-8AI-1MO-IV ALLOY IN THE DUPLEX - ANNEALED CONDITION 
were the body-centered cubic beta phase. Dislocations, dislocation networks, and stacking faults were apparent in many areas in the foil (Figure 9). The observation of coplanar arrays of dislocations (Figure 9a), stacking faults (Flgure $9 \mathrm{~b}$ ), and extended nodes in dislocation networks (Figure 9b) suggest that the stacking fault energy of the alloy was quite low. The reasons for the structural contrast in regions such as shown in Figure $8 a$ have not yet been determined; however, it is probable that hydrogen was charged into the samples during foil preparation. Hydride contamination has been shown to produce such contrast effects in titanium alloys ${ }^{(3)}$.

During foll preparation, the thinning operation caused preferential attack to occur along the alpha beta phase boundarles and along alpha grain boundaries, as previously reported(1). It is interesting to compare this preferential attack to the mode of attack that occurs during preparation of stainless steel foils.(4,5) In austenitic stainless steels stress corrosion cracking normally occurs along transgranular paths, and stacking faults and coplanar arrays are believed to be the susceptible paths. Preferential attack occurs along these paths during preparation of thin folls of stainless steel, Just as preferential attack and stress corrosion cracking occur along grain and phase boundaries in Ti-8Al-1Mo-1V alloy. This comparison suggests that a corrosion phenomenon plays a major role in crack propagation in both stainless steels and titanium alloys.

The morphology of hot-salt cracking in a U-bend sample from heat D-3420 exposed to sea salt and air at $1200^{\circ} \mathrm{F}$ was described previously in some detail. (1) The cracks were fllled with corrosion products, presumably an oxide. During the past quarter, cracking was studied in a sample from the same heat of alloy exposed for two weeks to sea salt and air at $650^{\circ} \mathrm{F}$. As in the previous sample, the cracks predominantly followed the alpha-beta interfaces and the alpha grain boundaries; however, some indications of transgranular cracking were noted (Figure $10 \mathrm{a}$ ). The cracks produced at $650^{\circ} \mathrm{F}$ (Figure 10b) were much finer than those produced at $1200^{\circ} \mathrm{F}$ (Figure IOc) and little or no oxlde was apparent within the cracks. In addition to the formation of hot-salt cracks, the two-week exposure at $650^{\circ} \mathrm{F}$ produced more of the fine second phase within the alpha grains (see Reference 1 for a discussion of this phase). 


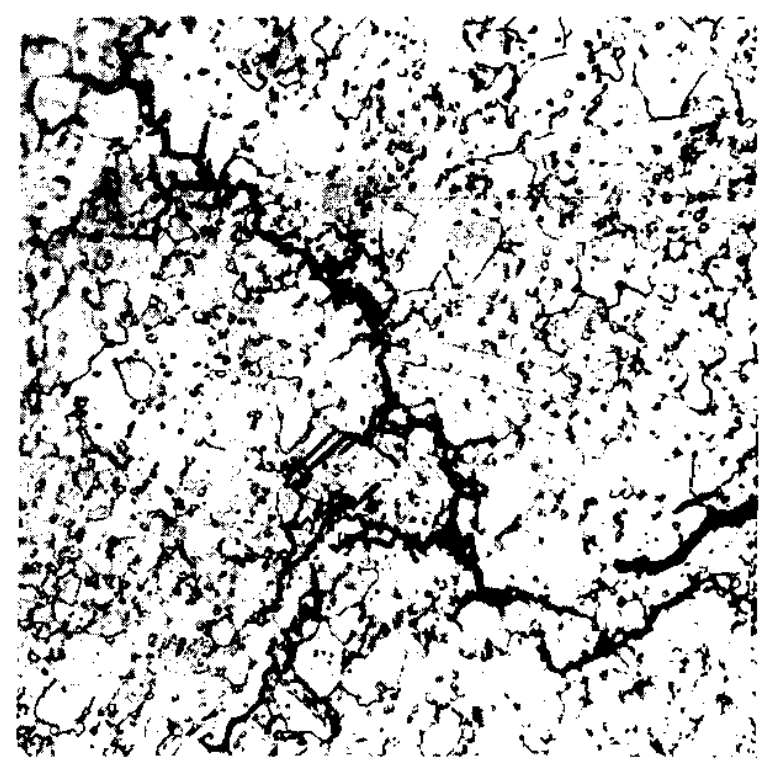

a. Crocked at $650^{\circ} \mathrm{F}$. Note traces of transgranular cracking. $500 \mathrm{X}$

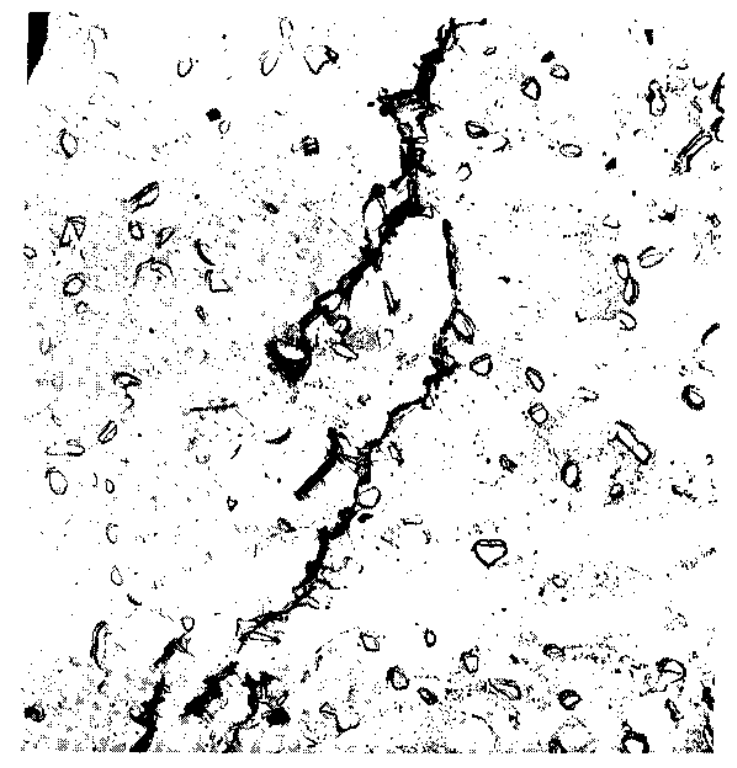

b. Cracked a+ $650^{\circ} \mathrm{F} \cdot 1500 \mathrm{x}$

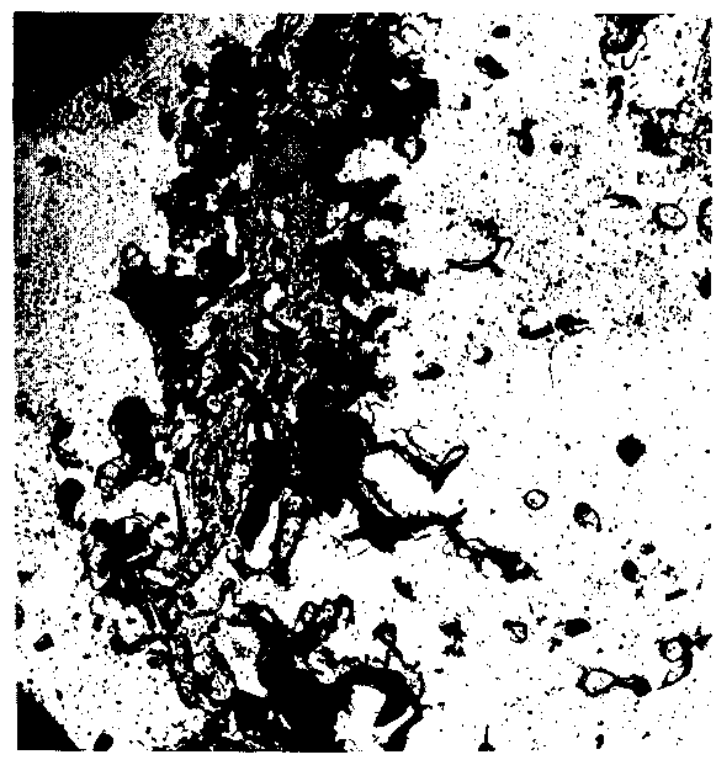

c. Cracked at $1200^{\circ} \mathrm{F} .1900 \mathrm{X}$

FIG. 10 COMPARISON OF HOT-SALT CRACKS FORMED AT 650 AND $1200^{\circ} \mathrm{F}$. Cracks formed at $650^{\circ} \mathrm{F}$ were finer and contained little or none of the oxide seen in the crack formed at $1200^{\circ} \mathrm{F}$ 


\section{REFERENCES}

1. S. P. Rideout, M. R. Louthan, and C. I. Selby. Stress Corrosion Cracking of Titanium Alloys, Progress Report - April 1-June 30, 1964. USAEC Report DP(NASA)-917, E. I. du Pont de Nemours \& Co., Savannah River Laboratory, A1ken, S. C. (1964).

2. G. Martin. Investigation of Long Term Exposure Effects Under Stress on Supersonic Transport Structural Alloys. USAEC Report NA-64-658, North American Avlation, Inc., Los Angeles Division, Los Angeles, Calif. (1964).

3. M. J. Blackburn. Private discussion.

4. M. R. Louthan. Stress Corrosion Cracking of Type 304 Stainless Steel, Status Report - March I, 1964. USAEC Report DP-907, E. I. du Pont de Nemours \& Co., Savannah River Laboratory, Aiken, S. C. (1964).

5. P. R. Swann. "Dislocation Substructure vs Transgranular Stress Corrosion Susceptibility of Single Phase Alloys." Corrosion, Vol 19, p. 102t-112t (1963).

6. The Salt Corrosion of Titanium Alloys at Elevated Temperature and Stress - Progress Report. USAEC Report TML-88, Battelle Memorlal Inst., Titanium Metallurgical Lab., Columbus, Ohio (1957). 